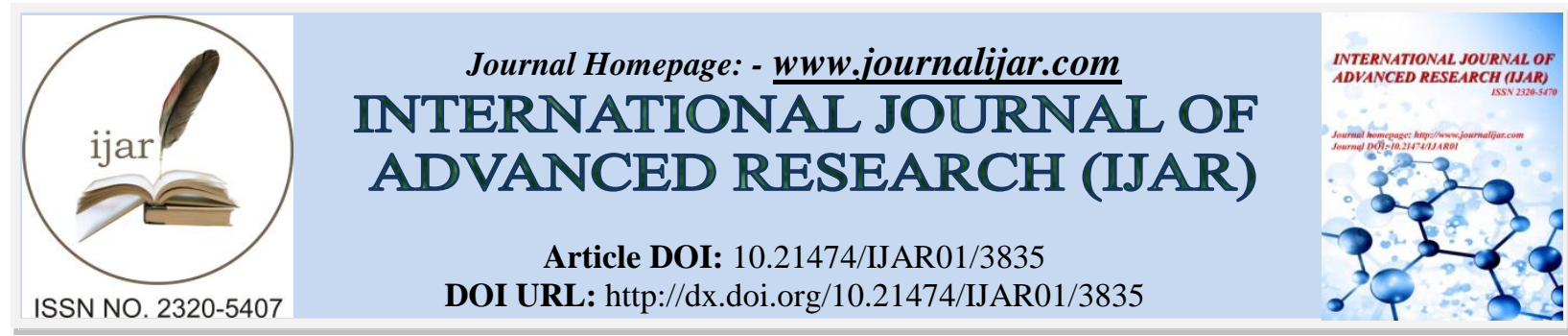

RESEARCH ARTICLE

\title{
CROSS-BORDER TRADE AND SECURITY IMPLICATIONS TO NORTH-EASTERN NIGERIA WITH PARTICULAR REFERENCE TO BORNO STATE: A HISTORICAL OVERVIEW.
}

\author{
Bukar Gaji* \\ Department of History, Faculty of Arts, University of Maiduguri, Borno State, Nigeria.
}

\section{Manuscript Info}

Manuscript History

Received: 01 February 2017

Final Accepted: 02 March 2017

Published: April 2017

\section{Abstract}

This paper examines trans-border trade and security in North-Eastern Nigeria with particular reference to Borno State. The phenomenal rise in smuggling of goods such as money landering and drug trafficking and other trans-border crimes within the border areas with Borno State has generated much concerns to scholars and policy makers. Transborder trade is growing in scale and momentum without a corresponding clear and coordinate strategy for dealing with this hydraheaded monster in the sub-region. This significantly affects the economies of not only Borno, North-Eastern region of Nigeria but also the countries of Niger, Chad and Cameroon. Cross-Border trade affect the joint security effort and stability of the continent of Africa. The stability of a country in terms of physical security is necessary for economic development when considered within the context of transborder trade. In a continued search for better understanding and cooperation, states or security gestures of good neighbourliness become imperative. The intensification of industrialization that harps on the production of qualitative products that can compete effectively with imported or smuggled products, the country can then truly benefit from globalization and smuggling will be rendered unattractive considering the fact that Nigeria has a land border as well as over 4,000skm running from Malaville, North of the Republic of Benin, stretching through Kebbi State, Sokoto, Kistna, Jigawa, Yobe, Adamawa, Borno and then to Cameroon, up till Mfum in Cross River state, bordering Cameroon, for operatives of the Nigeria customs, immigration and Nigeria drug law enforcement agent on one hand and on the other hand the army of unrepentant smugglers, it is made possible by the thousands of illegal crossing on these borders. Problems caused by porous borders in Borno State over the years, almost put the economy of the country to a halt. The government therefore, needs to evolve a new approach to securing the border, one that includes as integrated mix of development-inventions for border communities trained and dedicated officials and enhanced border situation awareness infrastructure.

Copy Right, IJAR, 2017,. All rights reserved. 


\section{Introduction:-}

Borno State evolved in 1976 out of the defunct North-East state which had itself emerged from the defunct northern Nigerian region in 1967. North-Eastern State of which Maiduguri, the present capital of Borno State was the headquarters; politically consist of Borno, Bauchi and Gongola States (1967-1991).Moreover, the Babangida regime added three more states in 1991 out of the existing three states in the north-east which included, Yobe State, Gombe state and Taraba States, Yobe State out of old Borno State, Gombe State out of old Bauchi State and Taraba State out of Gongola State. The Abacha regime set up the Arthur Mbanefor for committee with the sole aim of restoring the country. In his broadcast to the nation at Independence Day on October 1, 1995, Abacha announced the government's decisions on the 1995 draft constitution as well as the transition programme. In general, government accepted the important provision in the draft constitution, the most critical of which was the principle of rotational presidency. Thus, the office of the president should rotate among the six geo-political zones into which the country had been accordingly divided. These were North-East, North-West, Middle Belt, South-East, South-West and the Southern Minorities (now-called South-South). Thus the birth of North-East which comprises, Adamawa, Bauchi, Borno, Gombe, Yobe and Taraba States which are presently bedevilled by security threats as a result of insurgency. But this is not the terms and reference of this study. This study dwells on cross-border trade and insecurity, Borno State as a case in point.

The movement from the Middle East towards the South and West is a common feature of migration patterns of many of the people of Africa South of the Sahara. Lying within latitude $10^{\circ} \mathrm{N}$ and $14^{0} \mathrm{~S}$ and longitude $11^{0} 30 \mathrm{~N}$ and $13^{0} \mathrm{E}$, Borno State which has an area of $70,898 \mathrm{Km}^{2}$ is the largest state in the federation in terms of land mass-located in the North-Eastern corner of Nigeria, the state occupies the greatest part of the Chad basin and shares borders with the Republic of Niger to the North, Chad republic to the-east and Cameroon to the east. Furthermore, within the country its neighbours are Adamawa to the South, Yobe to the West and Gombe to the South West. Based on the 2006 census figures, Borno State has a population of 4,588,668 and population density of approximately 60 inhabitants per square kilometres Borno State, which is essentially an agrarian society. Contacts between the Nigeria area and the outside world to the north and north-east took place long before the advent of Islam. This was largely through trade and the continual migrations of people from the north to south into Nigeria area partly as a result of the gradual reduction in the amount of rainfall in the Central Sahara regions and other nearby regions or areas in the north.

Borno State used to be the centre of Trans-Sahara Trade and its strategic location favoured trade activities across the Sahara. Most baseline surveys indicate that the majority of informal cross-border trade is through smuggling in illegal importation of goods to neighbouring countries of Cameroon, Chad and Nigeria republics. These traders engaged in these trade activities as their sources of income and economic activities. The trans-border trade in Borno involve trade in processed, or non-processed merchandise which may be legal inputs or exports on one side of the border and illicit on the other side and vice-versa on account of not having been subjected to statutory border formalities such as custom clearance. There is no established means of transportation and these may range from haulage, by beast of burden, porters' canoes, to hired motorised transport such as buses and motorcycles. The NorthEastern region is bedevilled with insecurity as a result of the porosity of its borders as the region is situated at the borders of the three countries of Niger, Cameroon and Chad of which Borno State is contagious as it is the most affected as far as security architecture is concerned.

The mass movement of goods and people as well as mass importation of fire arms attested to this large volume of illegal trade and smuggling activities. It is unfortunate that Borno State has its fair share of insecure borders which breed insecurity and Borno man has grown poorer over the past decades, notwithstanding enormous opportunities that would have better its lots had it been that the borders are made more secured and legal business allowed to flourished. The paper adopts concepts that are critical and thematically dominant such as security, border and trade.

\section{Some Conceptual Clarifications:-}

There are concepts that are central part of this analysis that formed the most important aspects of the body of the paper they include: security, and trans-border trade.

\section{Security:-}

This is a common concept. Indeed security is an ambiguous term which covers a number of things. In a normative sense, security is about orderly existence of things. It is a state of protective environment. Also security measures the absence of threat to life, liberty, property and core values. Security also measures the absence of fear, anxiety, 
tension or apprehension of being in danger of losing life, liberty, property, and core values. When taken together, security can be taken to mean or represent or even express the absence or even express the absence of threat and/or fear in a social system. ${ }^{i}$ A nation is secure to the extent that it is not in a position to lose core values, like property and liberty, and if it wishes, to deter aggression or win war when unavoidable. ${ }^{\text {ii }}$ Most writers agree that security is a contested concept. There is consensus that it implies freedom from threats to core values (for both individuals and groups), but there is a major disagreement about whether; the main focus of inquiry should be, on individual, national, international or global security. For much of the cold war period most writing on the subject was dominated by the idea of national security, which was largely defined in militarized terms. The main area of interest for both academics and statesmen tended to be on the military capabilities that their own states should develop to deal with the threat that faced them. ${ }^{\text {iii }}$

Trans-Border trade: There are many definitions of trans-border trade. This trade involve legitimately produced goods and services, which escape government regulatory framework thereby avoiding certain tax and regulatory bodies or burdens hence fully or partly avoiding payment of duties and charges. Such trade include those which pass through unofficial routes and avoid customs controls, as well as those that pass through official routes with border crossing points and custom offices yet involved illegal practices. ${ }^{\text {iv }} \quad$ Such practices can comprise under-invoicing (i.e. falsifying the description of products so that they are misclassified as products subject to lower trariffs), misdeclaration of the country of origin with or without clandestine operations such as secret deals involving formal importers, exporters, customs and other public officials. ${ }^{\mathrm{v}}$ Trans-border trade or smuggling is referred to as parallel trade. It is a normal market response to cumbersome, time consuming, export regulations and regional price distortions, and should be encouraged as a means to increase intra-regional trade and organization meet local demand markets and ensure regional food security. ${ }^{\mathrm{vi}}$ The populace breaks state laws and regulations which they respect as unacceptable in order to survive in the light of the state's incapacity to satisfy the basic needs of the impoverished masses.

Smuggler engages in the distribution of prohibited goods and services deriving lucrative income that competes directly with trade in food and cash crops. The conditions at the border are so impoverished and pathetic that it necessitated illegal trade by the cross-border trades. These are no macro-economic stability and investment opportunities to attract investment, so smuggler has no choice than to engage in the illicit business, but it should not be encouraged. Hellener further posited that;

You can see them shutting in and around the border areas with Borno by motorbikes, horses, donkeys, camels cows and boats carrying goods like petroleum, clothes, foodstuff, and other assorted goods. Also the informal livestock traded includes camels, cattle goats and sheeps: countries include Chad and Niger, while key consumer markets are located in Gamboru-Ngala Banki, Kasuwan Shanu in Maiduguri otherwise known as cattle market. ${ }^{\text {vii }}$

Livestock trade requires long distance travel on food, since in these areas transport infrastructure is usually poor. Unfortunately, cross-border trade takes place against a backdrop of insecurity to persons and goods from corrupt law enforcing agencies or cross-border robbing gangs or syndicates. At the border, corrupt law-enforcing agencies often, take advantages of the local traders' lack of knowledge of customs procedures to take bribes. Traders carrying money risk of having money seized in some border areas, in Borno State have recorded high incidences of rapes lack of effective policing at border points, markets increases the incidence of crimes against traders forcing them to travel in groups to protect themselves, or simply use informal routes. ${ }^{\text {viii }}$ Borno State needs authentic social and economic development that can guarantee political and social security of the people. Sometimes security of the people. Sometimes security operatives at the border check products of aliens and deprived them of their monies and also collect bribes and allow the individual pass the border.

\section{Trans-Border Trade and Questioning Aspects of, Social Movement, Immigration and Customs Laws in a Democratic Nigeria:-}

Parallel trade and parallel economy have been used to denote unofficial economic activities such as prostitution or drug trafficking. ${ }^{\text {ix }}$ The term parallel refer to the movement of legal goods through illegal or unofficial channels, thus distinguishing it from informal productive and small scale services activities, on one hand and criminal or underground activities on the other. This definition includes both illegal cross-border trade with the West African country of Niger and central African countries of Chad, Cameroon and Central African Republic. Nigeria's crossborder trade with the Central Africa region particularly in its north eastern frontiers are conducted through three 
border markets of Banki, Gambaru-Ngala and multi axis. The official data covers value of imports and exports between Nigeria and its neighbours, Chad, Cameroon and Central African Republic and Niger Republic. However, much of these transactions are conducted informally and because of its illegal status goes unrecorded. The official, trade between Borno State and its borders/neighbours has some specific routes and it backed by the laws of the countries concerned and is based on the principles of reciprocity guided by the preferential treatments. Laducer write those;

The movement of people in these areas are accentuated by growing security problems in Borno State and other associated security problems such as religious crises, boundary disputes and contacts between herders and farmers, fuelled by the proliferation of small arms and light weapons. The weapons were smuggled into the country mostly from the central African states of Chad and Niger Republic in West Africa as well as Libya and Somalia. ${ }^{x}$

The flow of such weapons have sufficiently weaponries the North-Eastern part of Nigeria and by extension Borno as the armed insurgents who have considered themselves religious champions wreak havoc on the national political economy. The expanding armed insurgence in North-Eastern Nigeria -Borno poses a serious threat to Nigeria's interest thus:

1. Organised crime syndicates operate a major regional continental and global insurgency. They are backed by well-armed and increasingly well financed militias and a growing more coherent and also operating with greater autonomy while fuelling adventurism and regional conflict.

2. Insurgency in Northern-Eastern Nigeria is fully linked with international criminal syndicates operating as far as the shores of Niger, Somalia and central Africa Republic.

3. The escalation of violence in North-Eastern Nigeria might cause a significant decrease in the volume of peace and might impact harshly on both the region's future economic, social and political fortunes.

4. There is now high level of weapons proliferation throughout the region thereby resulting in the encouragement of militias with considerable fire power, extensive money laundering and alleged linkage to foreign donors and their domestic collaborators. Reversing this trend become the preoccupation of the army, customs and exercise and the immigration department and integrate the questioning aspects of the social movement and impose extant laws that governs the curtailment of illegal intrusion and illegal movement of goods, services and of people to and from.

However, there is ray of hope as the military under the Buhari dispensation, and so far the insurgents have been degraded and their supplies have been cut off and have lost focus, illegal infiltration into Nigeria has been checked and the people are more secured and have started returning to their home after prolong and avoidable insurgency. Nigeria has the best military in the world given the required arm and have so far shown spectacular gallantry in reducing insecurity in the North-Eastern Nigeria.

\section{The Nigeria National Security System: An Overview:-}

A nation is secured to the extent that it is not in a situation to lose its national sovereignty and independent and core values, and if it wishes to deter aggression or win wars if unavoidable. National security presupposes the existence of a nation with shared consciousness as people who have agreed to live and work together. Every organ in the society is used to promote security consciousness. In this way, the nation and its survival is uppermost to individuals, associations, political parties and pressure groups, military and Para-military bodies but the shared concern of every one. ${ }^{\mathrm{xi}}$ Although Nigeria has relative advantages over other Sub-Saharan African countries in terms of basic elements of power such as land size, population, natural resources, geopolitical locations etc. Nigeria's active involvement in the United Nations organizations and its agencies in particular, Nigeria's active anti-apartheid posture in the 1980s and its ubiquitous role in other organizations expose the country of the machination of imperial powers. Thus, the sources of threat to Nigeria's national security could be broadly identified as:

1. External forces

2. Internal elements. We are here concerned primarily with internal threats. As far as Nigeria is concerned, external threats to national security can be grouped into three.
a. Threats from neighbouring countries
b. Threats from African countries and
c. Threats from other imperial powers 
The concern of national security is often defined in relation to the issue of national defence. Defence has to do with the whole state apparatus for resisting attack which in this case includes the sum total of the military resources of country. Security in this context is defined simply as freedom from danger or relative freedom from aggression and unwarranted violation. In other words, the amount of security a country enjoys is a reflection of its defence system. According to Imohbighe;

Security has been seen as the priority obligations of the state or governments. About how best to achieve national security, writers like Hobbes, Machiavelli and Roseau tended to paint a rather pessimistic picture of the implications of state sovereignty. There is no doubt that national security is being challenged by the forces of globalization, some of which have a positive effect bringing states into greater conflict with each other, while others have a more effect. ${ }^{\text {xii }}$

Whether and how greater national security can be achieved still remains the hardest nut of all to crack. Despite efforts being put in place by both state and federal governments in the derive for the intensification of security, there appears grey areas to be contended with. This include under funding of the security agencies, absolute equipments, low wages/salaries, poor training, poor access to telecommunication and porosity of our borders. The moral of the security outfit should be improved.

\section{Trade Routes Linking Borno and the Border Towns and the Volume of Economic Activities:-}

There are three main trade routes that are internationally known to be legal with the four countries of Niger, Chad, Nigeria and Cameroon Republics. The Bama-Banki route, Dikwa-Ngala route Damasak-Dusthi-Difa and Gaidam Maine route. Then we have the illegal routes that bound the porous borders of North-Eastern Nigeria where Borno is strategically at the centre of attention and significance. Specifically these trade routes are critically important to the economic growth that it is carried out within the ambit of the laws that governs our national border but unfortunately, these routes are not followed legally thereby hampering the statutory laws and reduces. Productivity in the economic real sector by diverting resources. It also encourages crime and corruption which show economic growth and can distort the economy which is detrimental to the long-term economic development. In the words of Hockman;

Current global trends such as the growing interdependence between states and the opening of borders which exist alongside socio-economic, cultural, legal and political inequalities facilitates, the activities of trans-national criminal groups. The international economic crises of 2008 has had a number of consequence, some of which are unemployment a drop in remittance a fall in both the volume and prices of export direct foreign investment and a downward trend in tourism. ${ }^{\text {xiii }}$

As more people are working in informal sector others have joined organised crime networks such as trans-border trade that is illegally done, but some trade has semblances of illegality in few exceptional cases but generally here in Borno State the trade also has its illegality as laws governing customs are not strictly adhered to. ${ }^{\text {xiv }}$

\section{The Domestic Political Situation in North-East Nigeria and Principle of African Neighbourliness: Some Implications for National Security:-}

The domestic political situation in a nascent democracy like Nigeria doesn't in anyway help to sustain a formidable and potent security networking so long as in the domestic scene there is domestic politics of depending on neighbours to achieve political and economic interests though, there is nothing wrong in depending and safeguarding one's neighbour considering the fact that it is strictly in accordance with the required principle of good neighbourliness and reciprocal gestures. The domestic political scene in North-Eastern Nigeria and Borno State is such that politics breed thuggery and illegality since Nigeria's political independence in 1960, it has persistently retained as point of her primary objectives of her foreign policy. The critical questions of independence, national self-determination, national unity, national security, territorial integrity economic prosperity and the advancement of freedom and justice for the black race in Africa and those in the Diaspora. ${ }^{x v}$ These were and still are not fully observed and practiced by the politicians and this really hampers security of the region, and thereby impacting on Borno State and her neighbours along her international boundaries. To quote Shagari; 
Foreign policy as has been meticulously geared towards promoting good neighbourliness and a healthy respect for the principle of non-interference in the internal affairs of others, we should also conscious of the fact that Nigeria like most other regional powers, must learn to contend with the problems associated with leadership and the attendant responsibilities. This is the classic constraints which Nigeria will increasingly be upon to live with. ${ }^{\text {xvi }}$

Based on the 2006 national census figure, Borno State has a population of 4,156,193 is strategically located in the North-Eastern region of Nigeria. It is surrounded by mainly small francophone countries. Borno's closeness to these contagious francophone countries further underlines, not only the precariousness of Nigeria's continental roles but also poses immediate threats to its security and sovereignty as a nation. Although, North-Eastern Nigeria in general and Borno State in particular has relative economic superiority by their sheer size, population and natural resources, these exposes both the state and the geo-political zone to the hands of greedy barons.

Niger Republic is Borno's neighbour to the North; in terms of size, Niger Republic is about 1,267,209 $\mathrm{km}^{2}$ (mainly desert) with about 10.1 million people. Despite the fact that it is part of the francophone zone, it is closer to Borno State economically, politically and culturally. Inter-cultural exchanges, marriages, trans-border trade and the dominance of Kanuri and Hausa languages in the region have brought the people much closer, notwithstanding the official boundary. ${ }^{\text {xii }}$ Unfortunately, frequent cases of armed robbery, illegal cross-border trade, the disturbing incidence of clashes between farmers and cattle rearers in the northern part of Borno State, constitute serious social economic and security impediment to the consolidation of peace and stability in Borno-Niger border settlements. One other area of interactive diplomacy between Borno and Niger republic is over the popular, though misleading belief that Niger republic and its border constitutes weakest point of infiltration in Nigeria of religious fanatics particularly from North-Africa. Chad is another country sharing border with Borno State with about six million people. Chad republic is one of the poorest countries in the world until the recent discovery of oil in the country, with capital income of less than $\$ 300$ in 2010. The country faced serious internal conflicts leading to mass exodus of refugees into Borno State especially to parts of Maiduguri in the state capital occasioned by menace of robbery and importation of illegal arms and rebels. ${ }^{\text {xiii }} \quad$ Therefore, though relations between Nigeria and its neighbours of Chad and Niger are generally cordial, still a number of problems arise mainly because of the ineffective border controls. This has made it easy for illegal aliens to move in and out of Borno State unchecked.

The Cameroon republic is one of Borno's closer neighbours to the north and east. Cameroon is a central African country lies between latitudes $2^{0}$ and $14^{0} \mathrm{~N}$, bordered on west by Nigeria, on east by Chad and central African republic, on south by Congo and Gabon with an area of 475,425 square kilometres (183, 569 square miles), in the north some areas now in Cameroon, with others now Borno State Nigeria, were inhabited by the (saw), and then ruled by the Kenem-Borno empire. The Mandara kingdom founded in the $15^{\text {th }}$ century was occupied in the $16^{\text {th }}$ by Borno. Borno State and Cameroon republic share the longest border with Borno's territorial land and water clustered around large portion of mass land; each derives benefit from the other. These benefits includes exchanges of food items such as Banana, pineapple, rice maize and other assorted goods like shoes and leather bags, garments etc. i.e on the side of Cameroon, while Borno export goods such as plastic and iron jars, mattresses, plastics kettle, mats and other food items. Cameroon nationals flood Nigeria's border markets in Nigeria such as Banki, Kirawa and in the border fringes, so also Nigerian nationals are seen in Garwa, Marwa and Gwandere in Cameroon for business transaction in reciprocal terms. ${ }^{\text {xix }}$

However, there is constant security problem across the areas, some politically instigated, while others have socioeconomic factors at play. The Boko Haram insurgents does move around in and out of the some flash points along the border areas and strike at will and this trends and behaviours, extraordinarily constituted security nuisance to both countries. And it was this action by the Boko-Haramist that a security network was set up under the multinational task force; courtesy of Economic Community of West African States (ECOWAS). With the support and backing of United Nation (UN), of course the joint task force has been doing a wonderful job and the people are now under secured atmosphere kudos to the Nigerian army and the joint military multinational task force for crashing the activities of the militias and degrading them to zero tolerance. Nigeria's foreign policy principles since independence includes, maintenance of national sovereignty, security and territorial integrity, promotion of stability and friendliness in neighbouring countries. Nigeria's foreign policy objectives are more specific to the 
external environment especially, promotion of co-operation among African countries on matters of cultural, economic, political and diplomatic interest. ${ }^{\mathrm{xx}}$

\section{Concluding Remarks:-}

The domestic socio-economic, politico-cultural and security situation in Borno State is the incessant movement of political thugs and bandits and in main the activities of the Boko-Haram insurgents across the borders with Borno fuelled and encouraged by greedy elements for selfish political and economic interests and this is a minus to peace and development. During election period the state witnessed massive influence of nationals for voting purpose until recently when the security situation escalated that nationals of such countries are not allowed to infiltrate into Borno soil. The attitude of the foreigners as foot soldiers was as a result of poverty and this is indeed a source of threat to Nigeria's national security. The concept of national security is often defined in relation to the issues of national defence. Defence has to do with the whole state apparatus for resisting attacks which in this case includes the sum total of the military resources of a country. Security in this context is defined simply as freedom from danger or relative freedom from aggression and unwarranted violation. The other approach is to look at national security in relation to internal security. Although these terms are often interchangeably, internal security is said to cover the whole spectrum of freedom from danger and anxiety to that of sovereignty, which is the ability of a nation to protect its values from external and internal threats.

Security in this case has both an individual and national tolerance and dimension and in the case of Nigeria it has both internal and external implications. The spirit of African neighbourliness should be observed, respected, preserved and genuinely projected and at least by the states with international borders, so that frequent border dispute, cross-border trade, illicit movement of people and persistent political instability would be minimised if not completely eradicated or else they constitute a serious security challenge to North-Eastern Nigeria, and Borno State in particular. Unlikely all these problems have direct consequences for Nigeria's political stability and the country's resolve to pursue a viable and active foreign policy derives. The safety and well-being of the people of NorthEastern Nigeria and particularly the Borno people declined because of armed conflicts in Central Africa, Somalia, Sudan and to a lesser extent Niger, Libya and Mali Republics as a results of porosity of our borders, and lack of consistent and regular maintenance of law and a strong check. The region is afflicted with violence by insurgents who bring in sophisticated weapons into the country by crossing into and beyond the shores of our borders.

When European powers created artificial boundaries, these ethnic groups Shuwa-Arabs, Kanuris and Hausas regarded the political boundaries as the white men's boundaries. To put it another way they regarded the boundaries separating them from their brothers on both sides of the divide as something separating the French and the English and not something separating the Shuwa-Arab, the kanuri and the Hausa that are found in both countries. They continued to trade, marry and even exchange ideas on various aspects of their lives. Geographically, the closeness of Chad to Nigeria as well as Niger and Cameroon makes it possible for Chadians, Cameroonians and Nigerian to come to Borno for their personal needs and vice versa. Thus, it was not surprising to see Nigeria enter into bilateral relations over socio-cultural and economic fields which is a viable tools and means of exploiting the diverse human and natural potentials.

In the trading system Borno in North-Eastern Nigeria had steadily grown, exploiting the vast business endowment of her three neighbouring countries. However, the gains that had since over the years especially through certain activities were reversed by insurgency, criminality and barriers of insecurity which had hampered legal patterns of relations. Unfortunately, Nigeria's neighbours are not always very friendly; one interesting dimension of Nigeria's position of continental politics is the fact that the threats and challenges to Nigeria's role in Africa are actually closer home. Nigeria's geographical position vis-a-vis Borno State in North-Eastern Nigeria, Borno's neighbours and the pervasive presence of France in the francophone counties further underlines, not only the precariousness of Nigeria's continental role but also poses immediate threats to its very security and sovereignty as a nation.

\section{References:-}

1. Aja, A.A: Policy and Strategic Studies, Uncharted Waters of War and Peace in International Relations (Willy Rose and Apple Seed Publishing Coy. 1991). PP.34-35.

2. Lipman, W: US Foreign Policy Shield of Republic (Boston Little Brown and Co) cited in Aja, A.A. Co, 1943) P143.

3. Bayli, J: International and Global Security, (Oxford University Press, 2011) P233

4. Leeman. K: Global Society and International Security. (African Forum, Volume Six, 2001), P65. 
5. Mauthey, S: Global Society and International Security. (African Forum, volume Six, 2009) P112.

6. Kaltungia, C: International Issues. The global policies Wikipedia.

7. Helleiner, E: States and the Re-emergence of Global Finance: from Bretton Woods to the 1980s, (Cornell University Press, 1991) P102.

8. Kaltungia, C. International Issues. The Global Policies, (Wikipedia, 2001) P114

9. Macathy, U: Informal Cross Border Trade in Africa: Implications and Policy Recommendation, (Cambridge, University Press, 1987) P65.

10. Livdaucer, R: The Political Economy of International Capital Mobility (Basingtone Palgrave, Macmillan, 1987) P143.

11. Aja, A.A: Policy and Strategic Studies, Uncharted Waters of War and Peace in International Relations (Willy Rose and Apple Seed Publishing Coy. 1991). P36.

12. Imobighe I.A (1987). African Defence and Security: An overview, Forum, Nigeria Institute of International Affairs (NIIA) Lagos.

13. Hock man, B: The Political Economy of the World Trading System, (Oxford: Oxford University Press, 2009.

14. Notermans, T: Money, Markets and the State Social Democratic Economic Policies (Cambridge. Cambridge, University Press, 2007) P63.

15. Alkali, A.A. Issues in International Relations and Nigeria's Foreign Policy (Baraka Press Ltd, Ahmadu Bello way, Kaduna, Nigeria, 2003) P81.

16. Shagari, A.A U.S: Annual Foreign Policy Address by President Alhaji Usman Aliyu Shehu Shagari, (Nigeria Institute of International Affairs, Lagos, 1981) P126.

17. Kayode, A.O. Nigeria's Foreign Policy in the West-African Sub-region in the 1990s Unpublished Ph.D. thesis, Ahmadu Bello University, Zaria, 2001. P84.

18. Uwechue, R: Africa Today, African Books Limited (3 Galena Road, Hammersmith, London, W6 OLT, United Kingdom, 1991) P194.

19. Uwechue, R: Africa Today, African Books Limited (3 Galena Road, Hammersmith, London, W6 OLT, United Kingdom, 1991) P640.

20. Alkali, A.A. Issues in International Relations and Nigeria's Foreign Policy (Baraka Press Ltd, Ahmadu Bello way, Kaduna, Nigeria, 2003) P23. 